Journal of Maternal and Child Health (2018), 3(4): 242-251

https://doi.org/10.26911/thejmch.2018.03.04.01

\title{
Life Course Epidemiology on the Determinants of Stunting in Children Under Five in East Lombok, West Nusa Tenggara
}

\author{
Husniyati Sajalia'), Yulia Lanti Retno Dewi²), Bhisma Murti1) \\ 1)Masters Program in Public Health, UniversitasSebelas Maret \\ 2)Faculty of Medicine, UniversitasSebelas Maret
}

\begin{abstract}
Background: Stunting remains a challenging global health issue. It is estimated by Global Nutrition Report that 155 million children were stunted in 2017. Stunting is associated with an underdeveloped brain, with long-lasting harmful consequences, including diminished mental ability and learning capacity, poor school performance in childhood, reduced earnings and increased risks of nutrition-related chronic diseases, such as diabetes, hypertension, and obesity in future. This study aimed to examine the determinants of stunting in children under five in East Lombok, West Nusa Tenggara.

Subjects and Method: This was an analytic observational study with a case control design. The study was carried out in 31 posyandus (integrated family health posts) in East Lombok, West Nusa Tenggara, from April to May 2018.A sample of 186 children was selected by fixed disease sampling. The dependent variable was stunting. The independent variables were low birthweight (LBW), birth length, exclusive breastfeeding, history of infection disease, maternal age at pregnancy, maternal middle upper arm circumference (MUAC), and family income. The data were collected by questionnaire and analyzed by a multilevel logistic regression run in Stata 13.

Results: The risk of stunting increased with $\mathrm{LBW}(\mathrm{b}=3.51 ; 95 \% \mathrm{CI}=-0.28$ to $7.31 ; \mathrm{p}=0.069)$, maternal age at pregnancy $<20$ or $\geq 35$ years $(b=2.73 ; 95 \% \mathrm{CI}=0.38$ to $5.42 ; \mathrm{p}=0.047)$, andhistory of infectious disease $(b=3.70 ; 95 \% \mathrm{CI}=0.84$ to $6.56 ; \mathrm{p}=0.011)$. The risk of stunting reduced with high family income $(b=-2.15 ; 95 \% \mathrm{CI}=-4.37$ to $0.61 ; \mathrm{p}=0.057)$, birth length $(\mathrm{b}=-4.17 ; 95 \% \mathrm{CI}=-$ 7.42 to $-0.91 ; \mathrm{p}=0.012)$, exclusive breastfeeding $(\mathrm{b}=-3.24 ; 95 \% \mathrm{CI}=-5.63$ to $-0.85 ; \mathrm{p}=0.008)$, and maternal MUAC $\geq 23.5 \mathrm{~cm}(\mathrm{~b}=-4.53 ; 95 \% \mathrm{CI}=-8.09$ to $-0.97 ; \mathrm{p}=0.013)$. Posyandu had a contextual effect on the incidence of child stunting with $\mathrm{ICC}=15.00 \%$.

Conclusion: The risk of stunting increases with LBW, maternal age at pregnancy $<20$ or $\geq 35$ years, and history of infectious disease. The risk of stunting reduces with high family income, birth length, exclusive breastfeeding, and maternal MUAC. Posyandu has a contextual effect on the incidence of child stunting.
\end{abstract}

Keywords: Stunting, low birthweight, birth length, exclusive breastfeeding

\section{Correspondence:}

Husniyati Sajalia. Masters Program in Public Health, Universitas Sebelas Maret, Jl. Ir. Sutami No. 36 A, Surakarta 57126, Central Java. Email: sajalia@gmail.com. Mobile: +6281997987081

\section{BACKGROUND}

Nutrition problem is a problem faced at global level. According to Global Nutrition Report (GNR) data in 2017, prominent nutritional problems include stunting. Approximately 155 million children under five suffered from stunting (UN, 2015, WHO, 2015). The assessment of Nutrition Status (PSG) shows the prevalence of toddler stunting age $0-59$ month of year 2016 in Indonesia equal to 27.6\%. West Nusa Tenggara (NTB) province, including East Lombok regency, is one of the priority areas of the government in 100 districts that require the handling of nutritional problems (TNP2K, 2017).

Stunting is a mismatch between height and age, or commonly called short 
toddlers (WHO, 2014). Stunting is a public health problem that can pose a serious threat to global health because it can lead to less optimal growth and development potential (Perkins et al., 2017), and closely related to the risk of death in children under five (Acevedo et al, 2017).

According to WHO (2014) and Pusdatin of Ministry of Health (2016), the incidence of stunting can be caused by maternal, child, and environmental factors. Strengthening early detection and problem handling is essential to reduce the incidence of stunting and wasting (Dersoet, 2017). In this study, researchers wanted to know the effect on the individual level and contextual influence of posyandu on stunting events in infants in East Lombok.

\section{SUBJECTS AND METHOD \\ 1. Study Design \\ This was an analytic observational study with a case control design. The study was conducted at 31 posyandus (integrated health posts) in 4 East Lombok Health Centers, West Nusa Tenggara, Indonesia, from April to May 2018.}

\section{Populationand Sample}

The source population in this study was children aged 6-59 months at 31 posyandus in 4 puskesmas, ie Aikmel, Lenek, Kalijaga, and Wanasaba Health Center, East Lombok Regency. The sampling was fixed disease sampling technique to choose toddlers and stratified random sampling to choose posyandu. Subjects consisted of 186, coming from 6 subjects on each unit level 2 (posyandu).

\section{Study Variables}

The dependent variable was stunting. The independent variables were family income, maternal age during pregnancy, maternal MUAC, low birth weight (LBW), birth lenght, exclusive breastfeeding, history of infectious disease.

\section{Operational Definition of Variables}

Family income was defined as the monthly average of income or income in the last six months produced by the head of family/ other family members to meet daily needs. The data were collected by questionnaire. The measurement scale was continuous.

Maternal age at the time of pregnancy was defined as the age at which the mother in the condition of pregnancy expressed in year. The data were collected by questionnaire. The measurement scale was continuous.

Maternal nutritional status during pregnancy was defined as the maternal nutritional status described by the size of the upper arm circumference (MUAC) in centimeters $(\mathrm{cm})$ at the time of pregnancy. The data were collected by questionnaire. The measurement scale was continuous.

Low birth weight (LBW) was defined as the infant weight at birth less than 2500 grams weighed in the first hour after the baby is born. The data were collected by maternal and child book monitoring. The measurement scale was continuous.

Body birth length was defined as the length of the infant at birth, measured in the first hour after the baby is born, and expressed in $\mathrm{cm}$. The data were collected by maternal and child book monitoring. The measurement scale was continuous.

Exclusive breastfeeding was defined as a breastfeeding status started from children aged o to 6 months. The data were collected by questionnaire. The measurement scale was continuous.

The history of infectious diseases was defined as the history of childhood illness, such as diarrhea or respiratory infection, in the last six months. The data were collected by questionnaire. The measurement scale was continuous.

Stunting was defined as the nutritional status of children ages 6-59 months 
measured by age or height (HAZ), then compared to the anthropometric standards of child nutritional status assessment. The data were measured by infantometer (for child aged 6-24 months) and microtoise (for child aged 25-59 months).

\section{Data Analysis}

Univariate analysis was conducted to see frequency distribution and characteristic of research subject, while bivariate analysis using chi-square test and odds ratio calculation (OR) with 95\% confidence level (CI). Multivariate analyzes used a multilevel logistic regression through multilevel approaches indicated by the value of Intra Class Corelation (ICC).

\section{Research Ethics}

Research ethics in this research include others, informed consent, anonymity, confidentiality, and ethical clearan done in Moewardi hospital Surakarta with number 384 / IV / HREC / 2018.

\section{RESULTS}

\section{Study subjects characteristics}

Subjects in this study consisted of 186 infants, consisting of 62 stunted children and 124 normal children. The frequency distribution of the sample characteristics is described in Table 1.

Table 1 shows that most of the subjects are male for (108, 58.06\%), aged $<24$ months $(98,52.69 \%)$. As many as 56 mothers (30.11\%) were at senior high school. Mostly, the mothers were housewive (150, 80.65\%).

\section{Univariate analysis of life course epidemiology on the determinants of stunting}

Univariate stunting analysis in this study included family income, maternal age during pregnancy, maternal MUAC, LBW, and birth length can be seen in table 2 . Frequency distribution of variable with categorical data includes exclusive breast- feeding and history of infectious diseases (diarrhea or Pneumonia) that can be seen in table 3 .

Table 2 shows that most children under five (43.01\%) coming from low income families $(<\mathrm{Rp} 700,000)$, maternal age during pregnancy (73.66\%) mostly in pregnant women at healthy reproductive age (20-35 years), and 77.96\% mothers had MUAC $\geq 23.5$. As many as $55.38 \%$ children had birth length $\geq 48 \mathrm{~cm}$.

Table 3 shows that the majority of study subjects (56.45\%) were exclusively breastfed, and $51.61 \%$ of children under five had a history of infectious diseases (diarrhea or ISPA / Pneumonia) in the last 6 months.

Table 1. Study Subject Characteristics

\begin{tabular}{lll}
\hline Characteristics & n & \% \\
\hline Gender & 108 & 58.06 \\
Male & 78 & 41.94 \\
Female & & \\
Children Age & & \\
$<24$ months & 98 & 52.69 \\
$\geq 24$ months & 88 & 47.31 \\
Maternal Education & & \\
No formal education & 7 & 3.76 \\
Did not pass primary school & 15 & 8.06 \\
Primary school & 50 & 26.88 \\
Junior high school & 44 & 23.66 \\
Senior high school & 56 & 30.11 \\
College & 14 & 7.53 \\
Maternal job & & \\
Housewife & 150 & 80.65 \\
Farmer & 6 & 3.23 \\
Labor & 5 & 2.69 \\
Entrepreneur & 16 & 8.60 \\
Private empoloyes & 5 & 2.69 \\
Civil servant & 4 & 2.5 \\
\hline
\end{tabular}

\section{Bivariate analysis of life course epidemiology on the determinants of stunting}

Bivariate analysis was done to observe the independent variables (family income, maternal age during pregnancy, maternal MUAC, LBW, length of birth, exclusive 
breastfeeding, history of infectious disease) with stunting. The result of bivariate analysis can be seen in table 4 .

Table 4 shows that family income, maternal age at pregnancy, maternal

Table 2. Frequency distribution of maternal age at pregnancy, maternal MUAC, birthweight, and birth lenght

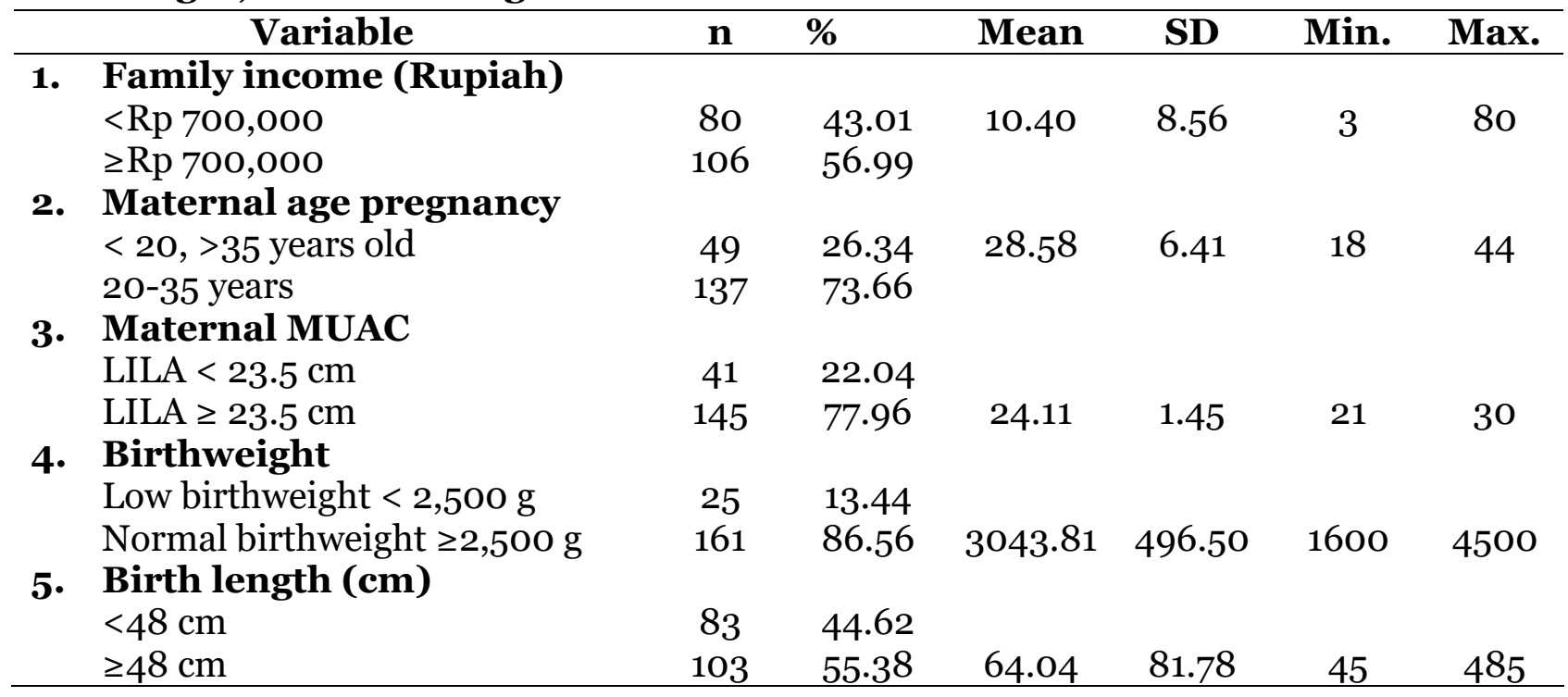

Table 3. The frequency distribution of study variables with categorical data

\begin{tabular}{lcc}
\hline \multicolumn{1}{c}{ Variables } & n & \% \\
\hline 1. Exclusive Breastfeeding & & \\
Exclusive breastfeeding & 105 & 56.45 \\
No exclusive breastfeeding & 81 & 43.55 \\
2. Infection History & & \\
Never had an infectious disease & 90 & 48.39 \\
Ever had an infectious disease (diarrhea or pneumonia) & 96 & 51.61 \\
\hline
\end{tabular}

\section{The results of multilevel analysis}

Multivariate analysis was conducted to see the effect of independent variables (family income, maternal age during pregnancy, maternal MUAC, LBW, birth length, exclusive breastfeeding, and history of infectious disease) to a dependent variable (stunting).

Table 5 shows that maternal age at pregnancy <20, >35 years $(b=2.73$; 95\% CI $=0.38$ to $5.42 ; \mathrm{p}=0.047$ ) and had a history of infectious disease $(b=3.70 ; 95 \% \mathrm{CI}=$
MUAC, LBW, exclusive breastfeeding, and history of infectious disease had a statistically significant effect on stunting. 
Journal of Maternal and Child Health (2018), 3(4): 242-251

https://doi.org/10.26911/thejmch.2018.03.04.01

Table 4. The results of Chi-square test

\begin{tabular}{|c|c|c|c|c|c|c|c|c|}
\hline \multirow{3}{*}{ Independent variables } & \multicolumn{4}{|c|}{ Stunting } & \multirow{3}{*}{$\mathbf{O R}$} & \multicolumn{2}{|c|}{$95 \% \mathrm{CI}$} & \multirow{3}{*}{$\mathbf{p}$} \\
\hline & \multicolumn{2}{|c|}{ Yes } & \multicolumn{2}{|c|}{ No } & & \multirow{2}{*}{$\begin{array}{l}\text { Lower } \\
\text { Limit }\end{array}$} & \multirow{2}{*}{$\begin{array}{l}\text { Upper } \\
\text { Limit }\end{array}$} & \\
\hline & $\mathbf{n}$ & $\%$ & $\mathbf{n}$ & $\%$ & & & & \\
\hline \multicolumn{9}{|l|}{ Family income } \\
\hline$<\operatorname{Rp} 700,000$ & 41 & 51.2 & 39 & 48.8 & 0.24 & 0.12 & 0.45 & $<0.001$ \\
\hline$\geq \operatorname{Rp} 700,000$ & 21 & 19.8 & 85 & 80.2 & & & & \\
\hline \multicolumn{9}{|l|}{ Maternal age at pregnancy } \\
\hline 20-35 years & 31 & 22.6 & 106 & $77 \cdot 4$ & 5.89 & 2.90 & 11.92 & $<0.001$ \\
\hline$<20,>35$ years & 31 & 63.3 & 18 & 36.7 & & & & \\
\hline \multicolumn{9}{|l|}{ Maternal MUAC } \\
\hline$<23.5 \mathrm{~cm}$ & 37 & 90.2 & 4 & 9.8 & 0.02 & 0.01 & 0.07 & $<0.001$ \\
\hline \multicolumn{9}{|l|}{ Birtweight } \\
\hline$\geq 2,500 \mathrm{~g}$ & 41 & 25.5 & 120 & 74.5 & $15 \cdot 37$ & 4.98 & 47.40 & $<0.001$ \\
\hline$<2,500 \mathrm{~g}$ & 21 & 84.0 & 4 & 16.0 & & & & \\
\hline \multicolumn{9}{|l|}{ Birth length (cm) } \\
\hline$<48 \mathrm{~cm}$ & 46 & $55 \cdot 4$ & 37 & 44.6 & 0.15 & 0.07 & 0.29 & $<0.001$ \\
\hline$\geq 48 \mathrm{~cm}$ & 16 & $15 \cdot 5$ & 87 & 84.5 & & & & \\
\hline \multicolumn{9}{|l|}{ Exclusive breastfeeding } \\
\hline No exclusive breastfeeding & 53 & 65.4 & 28 & 34.6 & 0.05 & 0.02 & 0.11 & $<0.001$ \\
\hline Exclusive breastfeeding & 9 & 8.6 & 96 & 91.4 & & & & \\
\hline \multicolumn{9}{|l|}{ Infection disease } \\
\hline No & 4 & 4.4 & 86 & 95.6 & 32.82 & 11.11 & 96.90 & $<0.001$ \\
\hline Yes & 58 & 60.4 & 38 & 39.6 & & & & \\
\hline
\end{tabular}

Table 5. Results multilevel analysis

\begin{tabular}{|c|c|c|c|c|c|}
\hline \multirow{2}{*}{ Independent Variable } & \multirow{2}{*}{$\mathbf{b}$} & \multirow{2}{*}{ SE } & \multicolumn{2}{|c|}{$95 \% \mathrm{CI}$} & \multirow[b]{2}{*}{$\mathbf{p}$} \\
\hline & & & Lower Limit & Upper Limit & \\
\hline \multicolumn{6}{|l|}{ Fixed Effect } \\
\hline Family Income & -2.15 & 1.13 & $-4 \cdot 37$ & 0.61 & 0.057 \\
\hline Maternal age at pregnancy & 2.73 & 1.37 & 0.38 & $5 \cdot 42$ & 0.047 \\
\hline Maternal MUAC & -4.53 & 1.82 & -8.09 & -0.97 & 0.013 \\
\hline LBW & $3 \cdot 51$ & 1.93 & -0.28 & $7 \cdot 31$ & 0.069 \\
\hline Birth Length & -4.17 & 1.66 & -7.42 & -0.91 & 0.012 \\
\hline Exclusive Breastfeeding & -3.24 & 1.22 & -5.63 & -0.85 & 0.008 \\
\hline History of disease & 3.70 & 1.46 & 0.84 & 6.56 & 0.011 \\
\hline \multicolumn{6}{|l|}{ Random Effect } \\
\hline Posyandu & 0.58 & 1.05 & 0.17 & 19.91 & \\
\hline Var (LBW) & 0.58 & 1.05 & 0.17 & 19.91 & \\
\hline Var (exclusive breastfeeding) & 0.58 & 1.05 & 0.17 & 19.91 & \\
\hline Var (birth length) & 0.58 & 1.05 & 0.17 & 19.91 & \\
\hline Var (maternal MUAC) & 0.58 & 1.05 & 0.17 & 19.91 & \\
\hline \multicolumn{6}{|l|}{$\operatorname{Var}($ constanta) } \\
\hline \multicolumn{6}{|l|}{$\mathrm{N}$ observation $=186$} \\
\hline \multicolumn{6}{|l|}{$\mathrm{N}$ group $=31$} \\
\hline \multicolumn{6}{|l|}{ Log likelihood= -26.95} \\
\hline \multicolumn{6}{|l|}{ Prob $>\mathrm{Chi}^{2}=0.215$} \\
\hline $\mathrm{ICC}=15.00 \%$ & & & & & \\
\hline
\end{tabular}

\section{DISCUSSIONS}

\section{The effect of family income on the incidence of stunting.}

The result of this study showed that monthly family income has a marginally significant effect on the incidence of stunting $(b=-2.15 ; 95 \% \mathrm{CI}=-4.37$ to 0.61 ; $\mathrm{p}=0.057)$. Children who came from family with high income decreased the risk of 
stunting by 2.15 times compared to children who came from family with low income.

The result of this study was supported by a study of Kismul et al. (2018), which stated thatpoverty was closely related to the prevalence of stunting. Toddlers who came from low income families have a very high risk of stunting. According to Islam et al. (2018), poverty also has a big role in influencing nutritional status and various health indicators in toddlers. Poverty could increase the incidence of stunting by 2.81 times, which mean that toddlers from low income families have the risk of stunting by 2.81 times compared to toddlers from families with average or high income.

Income was related to the purchasing power of food, in other words, income would affect the quality and quantity of food. The inability to buy diverse and nutritious foods by low income families could lead to higher stunting in toddlers. Inadequate food intake and the exposure to infection and lack of access to health services could increase the risk of stunting (Tariku et al., 2017).

\section{The effect of maternal age at preg- nancy on stunting}

The result of this study showed that there was a significant effect of maternal age at pregnancy on stunting $(b=2.73 ; 95 \% \mathrm{CI}=$ 0.38 to $5.42 ; \mathrm{p}=0.047$ ). Children from maternal age at pregnancy $<20,>35$ years had the risk of stunting by 2.73 times compared to chidren from mothers with 20-35 years of age at pregnancy.

This study was in line with a study by Chirande et al. (2015), which stated that mothers who were pregnant at risky age (<20, >35 years old) were more likely to have children with stunting, this might be because pregnant women $<20$ years old have no experience or knowledge in terms of child nutrition. This study found that there were $63.3 \%$ of mothers who were pregnant at risky age and they have stunting children.In addition, maternal age at pregnancy was associated with maternal age at birth delivery, where the maternal age at birth delivery has a statistically significant relationship with malnutrition in toddlers (Mohammed and Asfaw, 2018).

Women who became pregnant at mature age, which was $\geq 20$ years old, would be psychologically more prepared for pregnancy and more experienced in nurturing their children, including nutrition fulfillment (Ayuningrum et al, 2017).

\section{The effect of maternal MUAC on stunting}

The result of this study showed that there was a negative effect of maternal MUAC on the incidence of stunting $(b=-4.53 ; 95 \%$ $\mathrm{CI}=-8.09$ to $-0.97 ; \mathrm{p}=0.013)$. Children from mother with MUAC $\geq 23.5 \mathrm{~cm}$ were less likely to be stunted.

MUAC size was used as an indicator of chronic energy deficiency (CED). CED in pregnant women was closely related to fetal growth because the fetus was very depending on nutrients distributed by the mother through the placenta. According to Akombi et al. (2017), nutritional problems in pregnant women could cause growth disorders.

Viridula et al. (2016), reported that there was an indirect relationship between maternal MUAC at pregnancy and the incidence of stunting. A study by Ayuningrum et al. (2017), showed a positive and direct relationship between maternal nutritional status (MUAC $\geq 23.5 \mathrm{~cm}$ ) and stunting.

Most of mothers (90.2\%) with MUAC $<23.5 \mathrm{~cm}$ had a stunting children. Stunting begun in the womb, therefore, the prevention should also begun since the baby was in the womb, one of them was by considering the nutritional status of pregnant women. Pregnant mothers who have poor nutritional status were expected to pay much attent- 
Journal of Maternal and Child Health (2018), 3(4): 242-251

https://doi.org/10.26911/thejmch.2018.03.04.01

ion to their nutritional intake, one of the ways was to optimize complementary feeding.

\section{The effect of low birth weight on the incidence of stunting}

The result of this study showed that stunting was positively effected by low birth weight. Infants who were born with birth weight $<2500 \mathrm{~g}$ increased the risk of stunting compared to infant with normal birthweight $(\geq 2500 \mathrm{~g})$.

The result of this study was supported by Rahayu et al. (2018), which stated that there was a positive relationship between birthweight and stunting. Children with birthweight $<2500 \mathrm{~g}$ have a greater risk of stunting. According to Indria et al. (2016), birth weight has an effect on the child growth and development. Growth and development of children with low birth weight would be slower than toddlers who were born with normal weight. A study by Sanin et al. (2018) in Bangladesh found that history of LBW was a major predictor of stunting incidence in children who lived in the slums of Bangladesh.

Another study stated that toddlers who were born with LBW have greater risk of stunting by 1.6 times. Stunting begun in the womb and continued until the first 2 (two) years of life (Rabaoarisoa et al, 2017).

Nkurunziza et al. (2017) stated that mothers who can correctly assess the size of LBW and normal children tend not to have stunting. In other words, mothers who take the time to learn to evaluate the child's nutritional status were less likely to have a stunted child. This study shows that there were still many subjects who were classified as low education level, which can be an indication of the lack of maternal knowledge on nutritional status.

\section{The effect of birth length on stunting}

The result of this study showed that there was a negative effect of birth length on stunting. Birth length $\geq 48$ decreased the risk of stunting.

This study found that $55.4 \%$ of children with birth lenght $<48 \mathrm{~cm}$ more likely to experienced stunting. Rahmadi (2016), stated that birth length affects child growth.

Birth length has a significant relationship with stunting. If the measurement of birth length was done correctly, it could early identify the toddlers who have risk of stunting (Islam et al, 2018). Based on the descriptions above, it was known that the correct measurement and the appropriate instruments were very essential for early detection of stunting incidence.

\section{The effect of exclusive breastfeed- ing on stunting}

The result of this study showed that there was a negative effect of exclusive breastfeeding on stunting. Exclusive breastfeeding decreased the risk of stunting.

This study was in line with a study by Chirande et al. (2015), infants who were not exclusively breastfed were more likely to have stunting. WHO recommended the mothers to breastfeed their babies for 6 months, but after 6 months, the breast milk cannot provide enough nutrients so that supplementary foods were needed.

Children in this study who were not exclusively breastfed and have stunting were $65.4 \%$. Mothers who did not give exclusive breastfeeding argued that breast milk was not enough to fulfill the needs of the baby so that the infant was given food/ drink other than breast milk before 6 months old. 


\section{The effect of history of infectious diesease on the incidence of stunting}

The result of this study showed that there was a positive effect of history of infectious disease on stunting. Chidlren who had a history of infectious disease (diarrhea or pneumonia) in the last 6 months could increase the risk of stunting by 3.70 times, compared to toddlers who have no history of infectious disease (diarrhea or pneumonia) in the the last 6 months.

This study was in line with a study by Batiro et al. (2017), which stated that diarrhea has a relationship with stunting, this was because when the children had diarrhea, they would loss fluid and appetite and also absorption disorders. In addition, respiratory tract infections were also a risk factor for stunting. Children who have a history of respiratory tract infections were 3 times more likely to have stunting. Similar thing was stated by Akombi et al. (2017), the occurrence of fever and diarrhea could cause disruption on the growth of children, therefore, it was important to immediately treat the infectious diseases.

De Onis and Branca (2016) stated that nutritional problems were associated with infectious disease. Infectious disease could worsen the nutritional status through lack of appetite and impaired absorption, whereas those with nutritional problems would be susceptible to infectious disease.

\section{The effect posyandu on stunting}

The result of this study showed that posyandu had a contextual effect on stunting with $\mathrm{ICC}=15.00 \%$. The variations on stunting were $15.00 \%$ influenced by posyandu. Table 5 showed that the score of the ICC in this study was greater than the rule of thumb of $8-10 \%$, the contextual influence in this study was health center, and it was very important to be noted.
Posyandu facilitates to monitor the growth of toddlers which was done every month. The monitoring was using a Growth Chart (GC) to record the growth in weight based on age. While height measurements were done every week of weighing, which was 6 months in each health center with the help of cadres and health personnel. There were several constraints such as the limitations of the instruments. Measurement body height was having lack of attention than weighing. Similarly, the incidence of stunting received less attention, therefore, it often failed to recognize the stunting from an early age. Stunting was often considered as a normal thing in society because people were not fully aware of the consequences of stunting in the future.

Health center was one of the means that can be utilized to detect the stunting incidence in an early age. Based on the descriptions above, maximizing the use of health center, improving the quality of health center services, and providing quality human resources were some of the influential efforts for the prevention of stunting (Nazri et al, 2016).

Based on the results of this study, it can be concluded that there was a significant effect between maternal age during pregnancy, maternal MUAC, birth length, exclusive breastfeeding, and history of infectious disease on stunting. Posyandu has a strong contextual effect on stunting.

\section{REFERENCES}

Acevedo P, Esteban MTG, Ejeda NL, Gomez A, Marrodan MD (2017). Influence of malnutrition upon all-cause mortality among children in Swaziland. Endocrinología, Diabetes Nutricion. 64(4): 204-210. https://doi.org/10.1016/j.endinu.2017.01.008. 
Akombi BJ, Agho KE, Merom D, Hall JJ, Renzaho AMN (2017). Multilevel Analysis of Factors Associated with Wasting and Underweight among Children Under-Five Years in Nigeria. Nutrients. 9(1): doi: 10.3390/nu9010044.

Akombi BJ, Agho KE, Hall JJ, Merom D, Astell-Burt T, Renzaho AMN (2017). Stunting and Severe Stunting among Children Under-5 Years in Nigeria: A Multilevel Analysis. BMC Pediatrics. 17(1).doi: 10.1186/s12887-016-0770-Z.

Ayuningrum IY, Salimo H, Dewi YLR (2017). Path Analysis on Gestational Socio-economic Determinants of Nutritional Status in Children Under Five in Purworejo Regency Central Java. Journal of Maternal and Child Health. 2(1): 30-41. https://doi.org/10.26911/thejmch.2017.02.01.04.

Batiro B, Demissie T, Halala Y, Anjulo AA (2017). Determinants of Stunting Among Children Aged 6-59 Months at Kindo Didaye woreda, Wolaita Zone, Southern Ethiopia: Unmatched case control study. PloS ONE. 12(12). https://doi.org/10.1371/journal.pone. 0189106.

Chirande L, Charwe D, Mbwana H, Victor $\mathrm{R}$, Sabas K, Issaka AI, Baines SK, Dibley MJ, Agho KE (2015). Determinants of Stunting and Severe Stunting among Under-Fives in Tanzania: Evidence from the 2010 Cross-Sectional Household Survey. BMC Pediatrics. Vol. 15, No. 165. doi: 10.1186/s12887-015-0482-9.

De Onis M, Branca F (2016). Childhood Stunting: A Global Perspective. Maternal and Child Nutrition. 12(1): 12-26. doi: 10.1111/mcn.12231.

Derso T, Tariku A, Biks GA, Wassie MM (2017). Stunting, wasting and associated factors among children aged 6-24 months in Dabat health and demo- graphic surveillance system site: A community based cross sectional study in Ethiopia.BMC Pediatrics. 17(96). https://doi.org/10.1186/s12887-017-0848-2.

Indria GA, Murti B, Dewi YLR (2016). Path Analysis: Effect of Gestational Factors, Psychosocial Factors and Antenatal Class Program on Toddler Growth. 1(1): 53-61. https://doi.org/10.26911/thejmch.2016.01.01.08.

Islam MM, Sanin KI, Mahfuz M, Ahmed AMS, Mondal D, Haque R, Ahmed T (2018). Risk factors of Stunting among Children Living in an Urban Slum of Bangladesh: Findings of a Prospective Cohort Study. BMC Public Health. 18(197). doi: 10.1186/s12889-018-5101-x.

Kismul H, Acharya P, Mapatano MA, Hatloy A (2018). Determinants of Childhood Stunting in the Democratic Republic of Congo: Further Analysis of Demographic and Health Survey 2013-14. BMC Public Health. 18(74): doi: 10.1186/s12889-017-4621-0.

Mohammed S, Asfaw ZG (2018). Bayesian Gaussian Regression Analysis of Malnutrition for Children Under Five Years of Age in Ethiopia. Archives of Public Health. 76(21). https://doi.org/10.1186/s13690-018-0264-6.

Nazri C, Yamazaki C, Kameo S, Herawati DMD, Sekawarna N, Raksanagara A, Koyama H (2016). Factors Influencing Mother's Participation in Posyandu for Improving Nutritional Status of Children Under-Five in Aceh Utara District, Aceh province, Indonesia. BMC Public Health. 16(69). doi: 10.1186/s12889-016-2732-7.

Nkurunziza SN, Meessen B, Geertruyden JPV, Corachais C (2017). Determinants of stunting and severe stunting among Burundian children aged 6-23 
months: evidence from a national cross-sectional household survey. BMC Pediatrics. 17(1): https://doi.org/10.1186/s12887-017-0929-2.

Perkins JM, Kim R, Krishna A, McGovern M, Aguayo VM, Subramanian SV (2017). Understanding the association between stunting and child development in low- and middle income countries: Next steps for research and intervention. Social Science \& Medicine. 193: 101-109. https://doi.org/10.1016/j.socscimed.2017.09.039

Pusat data dan Informasi Kementerian Kesehatan Republik Indonesia (2016). Situasi Balita Pendek. Jakarta: Pusat Data dan Informasi Kementerian Kesehatan RI.

Rabaoarisoa CR, Rakotoarison R, Rakotonirainy $\mathrm{NH}$, Mangahasimbola RT, Randrianarisoa AB, Jambou R, ViganWomas I, et al. (2017). The Importance of Public Health, Poverty Reduction Programs and Women's Empowerment in the Reduction of Child Stunting in Rural Areas of Moramanga and Morondava, Madagascar. PLoS ONE. 12(10). https://doi.org/10.1371/journal.pone.0186493.

Rahayu RM, Pamungkasari EP, Wekadigunawan CSP (2018). The Biopsychosocial Determinants of Stunting and Wasting in Children Aged 12-48 Months. Journal of Maternal and Child Health. 3(2): 105-118. https://doi.org/10.26911/thejmch.2018.03.02 .03.0.

Rahmadi A (2016). Hubungan Berat Badan dan Panjang Badan Lahir dengan Kejadian Stunting Anak 12-59 Bulan di Provinsi Lampung. Jurnal Keperawatan. 12(2): 209-218.

Sanin KI, Islam MM, Mahfuz M, Ahmed AMS, Mondal D, Haque R, Ahmed T
(2018). Micronutrient Adequacy is Poor, but Not Associated with Stunting Between 12-24 Months of Age: A Cohort Study Findings from a Slum Area of Bangladesh. PLoS ONE. 13(3). https://doi.org/10.1371/journal.pone. 0195072.

Tariku A, Biks GA, Derso T, Wassie MM, Abebe SM (2017). Stunting and its determinant factors among children aged 6-59 months in Ethiopia.Italian Journal of Pediatrics. 43(112). https://doi.org/10.1186/s13052-017-0433-1

Tim Nasional Percepatan Penanggulangan Kemiskinan (2017). 100 Kabupaten/ Kota Prioritas untuk Intervensi Anak Kerdil (Stunting). Jakarta: Tim Nasional Percepatan Penanggulangan Kemiskinan.

United Nations (2015). Transforming our World: The 2030 Agenda for Sustainable Development. https://sustainabledevelopment.un.org/content/documents/21252030\%20Agenda\%2ofor\%20Sustainable\%2oDevelopment\%20web.pdf.

Viridula EY, Murti B, Suryani N (2016). Path Analysis on the Effect of Biopsychosocial and Economic Factors during Gestational Period on the Risk of Stunting and Development in Children under Five, in Nganjuk, East Java. 1: 180-189.

World Health Organization (2015). From MDGS to SDGs: General Introduction. http://www.who.int/gho/publications/mdgs-sdgs/MDGs-SDGs2O15_chapter1.pdf. (2014). WHA Global Nutrition Targets 2025: Stunting Policy Brief. http://www.who.int/nutrition/topics /globaltargets_stunting_policybrief.p df. 